University of Nebraska - Lincoln

DigitalCommons@University of Nebraska - Lincoln

Faculty Publications: Department of Entomology

4-1984

Management of the Rice Tungro Virus Vector Nephotettix

virescens (Homoptera: Cicadellidae) with Controlled-Release Formulations of Carbofuran

R. M. Wilkins

S. Batterby

E. A. Heinrichs

G. B. Aquino

S. L. Valencia

Follow this and additional works at: https://digitalcommons.unl.edu/entomologyfacpub

Part of the Agriculture Commons, and the Entomology Commons

This Article is brought to you for free and open access by the Entomology, Department of at

DigitalCommons@University of Nebraska - Lincoln. It has been accepted for inclusion in Faculty Publications:

Department of Entomology by an authorized administrator of DigitalCommons@University of Nebraska - Lincoln. 

permission.

Submitted July 20, 1983; accepted December 19, 1983; published April 1, 1984.

\title{
Management of the Rice Tungro Virus Vector Nephotettix virescens (Homoptera: Cicadellidae) with Controlled-Release Formulations of Carbofuran
}

\author{
R. M. Wilkins, ${ }^{1}$ S. Batterby, ${ }^{1}$ E. A. Heinrichs, ${ }^{2}$ G. B. Aquino, ${ }^{2}$ \\ and S. L. Valencia ${ }^{2}$
}

1. Department of Agricultural Biology, University of Newcastle upon Tyne, Newcastle upon Tyne, United Kingdom

2. International Rice Research Institute, Manila, Philippines

\begin{abstract}
Field trials were conducted in lowland flooded rice in the Philippines to evaluate a number of carbofuran controlled-release formulations in comparison with commercial formulations. The test formulations were based on a biodegradable matrix of pine kraft lignin and were used as granules of different sizes and also in the form of small strips. The release rates were assessed under field conditions by bioassaying rice plants in the field, using adult rice green leafhopper, Nephotettix virescens Distant. The lignin formulations with a high level of active ingredient (15-45\% by weight) gave as good or better control than the commercial 3\% granules in tests based on three application techniques: broadcast into the floodwater, soil incorporation, and root zone injection. The improvements in control levels of green leafhoppers were most marked with soil incorporation and root zone application. The best lignin-based formulation reduced levels of tungro virus infection from $23 \%$ for a conventional flowable carbofuran formulation to $1.0 \%$ at an application rate of $0.5 \mathrm{~kg}(\mathrm{AI}) / \mathrm{ha}$. At the same rate, the grain yield was increased from $3.56 \mathrm{t} / \mathrm{ha}$ to $5.5 \mathrm{t} / \mathrm{ha}$, using the controlled-released formulation.
\end{abstract}

Controlled-release formulations to improve the delivery of insecticides to crop plants have been developed and tested in a number of crops (Gauthier 1981). Delivery systems based 
on root uptake of systemic insecticides have included solid granules (Stokes et al. 1973), plastic laminates, a starch xanthide matrix, and microencapsulation (Gauthier 1981, Collins et al. 1981). In limited field tests many of these formulations have shown promise, but the formulations frequently are based on stable plastic materials with release kinetics dependent on diffusion processes. Such systems, apart from their potentially high formulation costs, have the drawback that complete release of the active ingredient is difficult to achieve and thus the efficiency of such devices is reduced. In a continuing program to evaluate controlled-release formulations for agricultural purposes, using biodegradable materials, a series of formulations based on kraft lignin has been prepared and tested in the field. Lignin, a by-product of cellulose isolation, can be plasticized by various materials (Allan and Neogi 1978) to form a matrix which then sustains the release of the material. The usefulness of lignin as a formulating agent can be extended by the use of derivatives (Dellicolli 1977), e.g., in the release of ethoprop for root knot nematode control, of 2,4-D for weed control, and of PCNB for fruit rot control (Dellicolli 1980). Kraft lignin itself has been used as a formulating agent for carbofuran in the control of pine tip moths (Thompson et al. 1981) and for 2,4-D in studies of conifer plantation establishment (Wilkins 1981a).

Carbofuran is a widely used systemic insecticide applied to soil for control of many insect pests of rice, including the green leafhopper, Nephotettix virescens Distant. Its efficacy in rice protection has been clearly demonstrated (Bowling 1970), and its efficiency in use under flooded conditions is improved by direct delivery to the root zone of the rice crop (Pathak et al. 1974). Thus, the potential benefits and disadvantages of controlled-release carbofuran formulations should be distinguishable under the constantly humid conditions of flooded rice culture in view of the research and development already done.

We prepared various formulations of carbofuran and then evaluated them under field conditions of flooded rice for efficacy and duration of control of $N$. virescens, control of other insect pests, and grain yields. The formulations were prepared as a matrix of carbofuran and kraft lignin, including modifiers, in a granular form. Details of the formulation properties are reported separately (Wilkins 1983). These formulations were evaluated, in comparison with commercial formulations as standards, for 3 consecutive years in the Philippines.

\section{Materials and Methods}

Field experiments were carried out on the farm of the International Rice Research Institute (IRRI), Los Banos, Laguna, Philippines, from 1979 to 1981. The soil of the rice fields on the farm is Maahas clay, and the water levels in the experimental fields were individually controlled.

\section{Formulations}

All test formulations were based on kraft lignin plasticized with carbofuran and other materials and granulated, and the granules were sieved to nominal particle size ranges. Their preparation and properties have been described by Wilkins (1981b). The test formulations used in this series of trials were prepared from carbofuran and lignin (CL 45) or with additional modifiers (CLF 45, CL 20, and CLFG 15). These formulations contained the percent, by weight, of carbofuran as indicated in the code name. Details of these formulations, 
as well as of the standards employed, are provided in Table 1 . The irregularly shaped granules were sieved to aperture size ranges from 0.4 to $1.0 \mathrm{~mm}$ or 1.0 to $1.4 \mathrm{~mm}$, or for liquid injection to give a microgranule of 0.3 to $0.5 \mathrm{~mm}$. To evaluate the importance of granule size, one lignin formulation was prepared in all three size ranges (see Table 1). For direct insertion into the root zone, the CLFG 15 material was prepared in sheet form ( $1 \mathrm{~mm}$ thick), which was then cut into strips of 3 by $25 \mathrm{~mm}$.

\begin{tabular}{llcc}
\hline \multicolumn{4}{l}{ Table 1. Carbofuran formulations used } \\
\hline & & Carbofuran & \\
Name & Formulation type & content (\%) & Size (mm) \\
\hline Carbofuran 3G & Granules & 3 & Sand based \\
Carbofuran 10F & Flowable & 10 & - \\
CL 45 & Granules & 45 & $0.5-1.4$ \\
CLF 45 & Granules & 45 & $0.5-1.4$ \\
CLF 45 & Granules & 45 & $0.5-1.0$ \\
CLF 45 & Granules & 45 & $1.0-1.4$ \\
CLF 45 & Microgranules & 45 & $0.3-0.5$ \\
CL 20 & Granules & 20 & $1.0-1.4$ \\
CLFG 15 & Strip & 15 & 1 by 3 by 25 \\
\hline
\end{tabular}

\section{Experimental Procedures}

The rice fields were prepared by the normal practices of plowing, rotovation, and leveling before transplanting. Rice seedlings (3-week-old, insect-susceptible variety IR22) were transplanted manually at a spacing of 25 by $25 \mathrm{~cm}$ into the prepared bed which was provided with low mud levees to separate the plots $(7$ by $5 \mathrm{~m})$. A randomized block design with four replicates was used. Normal crop management practices, including water management, weed control, and fertilizers, were employed with the exception of insect control. Assessments included the field bioassay done by caging test insects within a cylindrical mylar film cage placed around randomly selected plants, one cage per replicate. By the method of Heinrichs et al. (1981), young, laboratory-reared N. virescens female adults were inserted into the cages at regular intervals, and mortalities were determined at 24 and $48 \mathrm{~h}$ after placement in the cages. Ten insects per cage were used. In addition, natural pest infestations were assessed from damage caused by the whorl maggot, Hydrellia philippina Ferino, determined at 30 days after transplanting; counts of deadhearts resulting from stem borer, Scirpophaga incertulas (Walker); and visual estimates of N. virescens made at weekly intervals. Plant stand condition and growth were monitored, extent of virus (tungro) infection was noted (Anonymous 1980), and where possible, grain yields were taken.

Preliminary studies where carbofuran, monocrotophos, metacrate, and meobal formulations were compared in flooded rice conditions indicated that carbofuran was the most effective. Consequently, carbofuran was selected on the basis of field performance and on compatibility with kraft lignin as a formulating agent.

The incorporation of carbofuran controlled-release formulations into the soil of rice fields was evaluated. As a result of $\mathrm{pH}$ fluctuation of the irrigation water, the duration of insecticidal activity is curtailed in the aquatic environment. Thus, soil incorporation offers 
a better route of delivery to the rice plant roots (Aquino and Pathak 1976). Accordingly, the carbofuran lignin-based formulations were tested with soil incorporation under wet season conditions. The rice field was prepared in the usual way, and low levees around and between the plots were established. Sufficient granules for each plot were weighed, mixed with sand for better distribution, and broadcast manually onto the soil surface at $1.5 \mathrm{~kg}(\mathrm{AI}) / \mathrm{ha}$ and incorporated with a rototiller. The following day, 3-week-old rice seedlings of an insect-susceptible variety (IR22) were transplanted. Assessment included the standard field bioassay using insectary-reared Nilaparvata lugens (Stål) (brown planthopper) and $N$. virescens at $2,7,12,17,22,32$, and 42 days after treatment.

\section{Root Zone Injections}

Heinrichs (1979) has shown that direct injection into the root zone of rice plants improves the efficiency of systemic insecticides, such as carbofuran, against foliar insect pests. A manual row marker-injector has been developed at IRRI (Heinrichs et al. 1981); this device can inject small liquid volumes at a depth of $5 \mathrm{~cm}$ at 10 hills simultaneously. To evaluate the compatibility of lignin-based carbofuran formulations with this mode of application, a microgranule (size range $0.3-0.5 \mathrm{~mm}$ ) suspended in water thickened with agar or methyl cellulose was used in 1981. The low specific gravity (1.20) of the lignin formulations assisted good suspension of the granules. A 1-ml amount of suspension was injected per hill at concentrations to provide 0.5 and $1.5 \mathrm{~kg}(\mathrm{AI}) / \mathrm{ha}$. The standard treatment was carbofuran $10 \%$ flowable, appropriately diluted with water, at 0.5 and $1.5 \mathrm{~kg}(\mathrm{AI}) / \mathrm{ha}$ injected in a similar way. Within 1 day after injection 3-week-old rice seedlings were transplanted at the location of the injection points, giving a spacing of 25 by $25 \mathrm{~cm}$.

\section{Strip Application}

To compare the duration of activity of the granular formulations with that of a monolithic device, a small field experiment was conducted with CLFG 15. The treatment consisted of strips ( 3 by $25 \mathrm{~mm}$ ) cut from a 1-mm-thick sheet of the formulation. One strip glued to a strip of cardboard was inserted into each rice hill to a depth of $5 \mathrm{~cm}$ to give the equivalent of $1.5 \mathrm{~kg}$ (AI)/ha. Plot size for this experiment was 2 by $2 \mathrm{~m}$; the central 16 hills were treated, and the central four hills were used for bioassays. The treatment was replicated four times.

The experiment was carried out during the dry season. Rice (IR22) was transplanted on 4 February 1981, and the final treatments were made on 10 February 1981. All assessments were made, including mortality of $N$. virescens adults, whorl maggot (Hydrellia philippina) damage ratings at 30 days after transplanting (30 DT), percent deadhearts due to stem borers at $48 \mathrm{DT}$, the number of tillers per hill at $30 \mathrm{DT}$, and percent tungro virus-infected hills at $91 \mathrm{DT}$. Also at $91 \mathrm{DT}$, the number of panicle-bearing tillers per hill and the percent of panicles that were whiteheads due to stem borer feeding were assessed. Finally, at harvest, grain yields (15\% moisture content) were taken. Duncan's multiple range test was used to make comparisons among the treatment means (Gomez and Gomez 1976). 


\section{Results and Discussion}

The methods used for application of the granular formulations of carbofuran were soil incorporation before transplantation and root zone application, either by liquid injection or by direct insertion close to each rice hill. Each of these methods progressively reduces the distance between the placement of the chemical and absorption area of the rice plant, principally the roots. The greater efficiency of these methods has been demonstrated in field experiments (Aquino and Pathak 1976, Seiber et al. 1978, van Halteren and Sama 1976'). The bioassay results of the field trial carried out during the wet season 1980 are shown in Figure 1. In general, the lignin formulations performed as well or better than the standard commercial carbofuran 3G. Of the two formulations with a high level of active ingredient, the larger granule had a distinctly longer phase when carbofuran levels in the plant were building up. Thus, these formulations gave a peak control level at $22 \mathrm{DT}$ in contrast to carbofuran 3G which declined almost from the first measurement. CL 20 also showed faster initial release but at all times gave better control than carbofuran 3G. At similar levels of control (40\%), carbofuran 3G persisted 7 days as compared with 20 days for CL 20. No yield comparisons could be made, as the crop was subsequently lost due to typhoon damage.

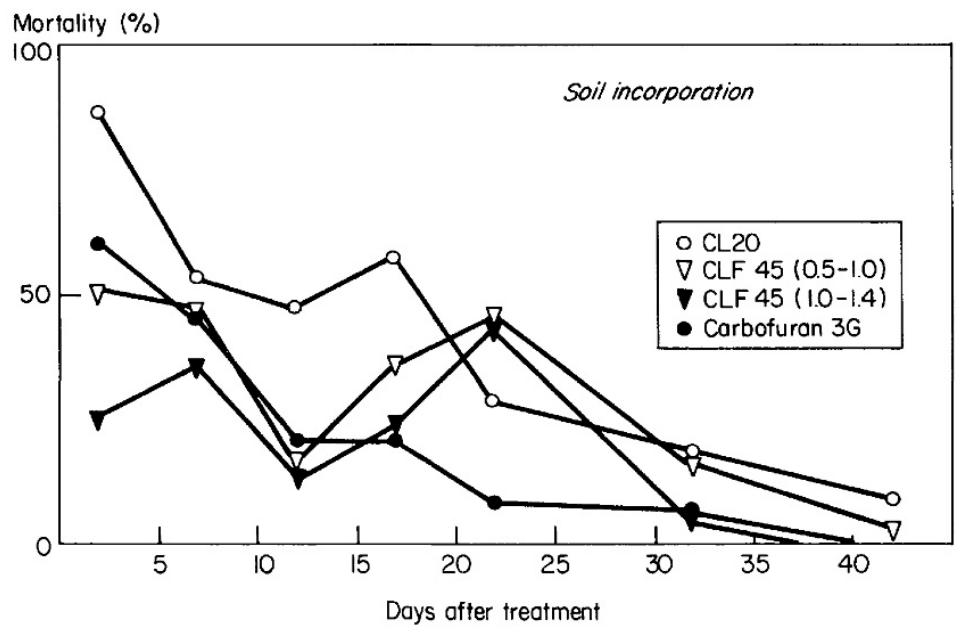

Figure 1. Mortality of $N$. virescens $48 \mathrm{~h}$ after caging on field rice plants treated with carbofuran formulations at $1.5 \mathrm{~kg}(\mathrm{AI}) /$ ha by soil incorporation. International Rice Research Institute, wet season, 1980.

The results of the field experiments carried out during the dry season 1981 are presented in Tables 2 and 3. To monitor the duration of release, the bioassays with the carbofuransensitive virescens were continued until levels of mortality were low and comparable to the controls. In this experiment, instead of comparison of the test formulation with a standard granule, the objective was to determine whether a controlled-release formulation could affect the adsorption and release of carbofuran by the soil. Some indication that this has been achieved is provided by $N$. virescens mortality at $1.5 \mathrm{~kg}(\mathrm{AI}) / \mathrm{ha}$. With the flowable 
formulation, control levels declined from 3 DT, whereas with CLF 45 microgranules peak control occurred at $18 \mathrm{DT}$; for the CLFG 15 strip inserted close to the rice plant, maximum effect occurred at 13 DT. The individual, slab-shaped strip formulation used in this field experiment demonstrated slow initial release and sustained in the highest control levels of all the formulations. The advantage of this geometry is in the modification of release rates over a wider range than with granules and its possible use in machine transplanting of rice. This type of matrix shape was similar to that used by Thompson et al. (1981).

Table 2. Mortality (\%) of field-caged N. virescens (48-h exposure) on rice plants treated with carbofuran formulations applied to the root zone; International Rice Research Institute, dry season, 1981

\begin{tabular}{|c|c|c|c|c|c|c|c|c|c|}
\hline \multirow[b]{2}{*}{ Treatment } & \multirow{2}{*}{$\begin{array}{l}\text { Formu- } \\
\text { lation } \\
(\% \mathrm{AI})\end{array}$} & \multirow{2}{*}{$\begin{array}{c}\text { Rate } \\
(\mathrm{kg}[\mathrm{AI}] / \\
\text { ha) }\end{array}$} & \multicolumn{7}{|c|}{ Mortality $(\%)$ at indicated days after treatment } \\
\hline & & & 3 & 8 & 13 & 18 & 24 & 34 & 44 \\
\hline $\begin{array}{l}\text { CLF } 45 \text { microgranules } \\
\text { (injection) }\end{array}$ & 45 & 1.5 & $78.1 \mathrm{a}$ & $74.7 \mathrm{a}$ & 69.1a & $92.5 \mathrm{a}$ & $60.0 \mathrm{a}$ & $37.5 \mathrm{ab}$ & $22.5 \mathrm{a}$ \\
\hline $\begin{array}{l}\text { CLF } 45 \text { microgranules } \\
\text { (injection) }\end{array}$ & 45 & 0.5 & $83.3 \mathrm{a}$ & $75.0 \mathrm{a}$ & $75.0 \mathrm{a}$ & $70.0 \mathrm{a}$ & $35.0 \mathrm{a}$ & $17.5 b c$ & $5.0 \mathrm{ab}$ \\
\hline $\begin{array}{l}\text { CLFG } 15 \text { (insertion } \\
\text { of strip) }\end{array}$ & 15 & 1.5 & $37.5 \mathrm{a}$ & $39.2 \mathrm{a}$ & $92.5 \mathrm{a}$ & $74.4 \mathrm{a}$ & $67.5 \mathrm{a}$ & $57.5 \mathrm{a}$ & $17.5 \mathrm{ab}$ \\
\hline $\begin{array}{l}\text { Carbofuran F } \\
\text { (injection) }\end{array}$ & 10 & 1.5 & $91.6 \mathrm{a}$ & $70.0 \mathrm{a}$ & $88.8 \mathrm{a}$ & $69.1 \mathrm{a}$ & $35.0 \mathrm{a}$ & $30.0 \mathrm{ab}$ & $17.5 \mathrm{ab}$ \\
\hline $\begin{array}{l}\text { Carbofuran F } \\
\text { (injection) }\end{array}$ & 10 & 0.5 & $63.5 \mathrm{a}$ & $35.3 a$ & $45.3 \mathrm{a}$ & $48.0 \mathrm{a}$ & $40.0 \mathrm{a}$ & $10.0 \mathrm{c}$ & $0.0 \mathrm{~b}$ \\
\hline
\end{tabular}

All values shown were corrected by Abbott's formula (Abbott 1925) to compensate for observed mortalities in the untreated control. Means within a column. followed by a common letter, are not significantly different at the $5 \%$ level, by Duncan's multiple range test.

Table 3. Field evaluation of controlled-release carbofuran formulations, International Rice Research Institute, dry season, 1981

\begin{tabular}{|c|c|c|c|c|c|c|c|c|}
\hline Treatment & $\begin{array}{c}\text { Rate } \\
(\mathrm{kg} \\
[\mathrm{AI}] / \mathrm{ha})\end{array}$ & $\begin{array}{c}\text { Whorl } \\
\text { maggot } \\
\text { damage, } \\
30 \mathrm{DT}\end{array}$ & $\begin{array}{c}\text { Tillers/ } \\
\text { hill, } \\
30 \mathrm{DT}\end{array}$ & $\begin{array}{c}\text { Dead- } \\
\text { hearts } \\
(\%), \\
48 \mathrm{DT}\end{array}$ & $\begin{array}{c}\text { Tungro } \\
\text { virus } \\
(\%), \\
91 \mathrm{DT} \\
\end{array}$ & $\begin{array}{c}\text { Produc- } \\
\text { tive } \\
\text { tillers/ } \\
\text { hill, } \\
91 \text { DT } \\
\end{array}$ & $\begin{array}{c}\text { White- } \\
\text { heads } \\
(\%)\end{array}$ & $\begin{array}{l}\text { Grain } \\
\text { yield } \\
\text { (t/ha) }\end{array}$ \\
\hline CLF 45 microgranules ${ }^{a}$ & 1.5 & $3.4 \mathrm{~b}$ & $12.1 \mathrm{~b}$ & $0.36 \mathrm{ab}$ & $1.09 \mathrm{c}$ & $21.3 b$ & $2.31 \mathrm{a}$ & $5.99 a$ \\
\hline CLF 45 microgranules $^{a}$ & 0.5 & $3.1 b$ & $14.7 \mathrm{a}$ & $0.10 \mathrm{~b}$ & $1.10 \mathrm{c}$ & $20.5 b c$ & $3.31 \mathrm{a}$ & $5.50 \mathrm{a}$ \\
\hline CLFG 15 strip $^{\mathrm{b}}$ & 1.5 & $3.9 \mathrm{~b}$ & 14.lab & $0.00 \mathrm{~b}$ & $0.00 \mathrm{c}$ & 26.1a & $0.69 b$ & $6.18 \mathrm{a}$ \\
\hline Carbofuran $10 \mathrm{~F}^{\mathrm{a}}$ & 1.5 & $1.5 \mathrm{c}$ & $16.5 a$ & $0.25 \mathrm{ab}$ & $0.62 \mathrm{c}$ & $20.2 b c$ & $2.68 \mathrm{a}$ & $5.75 a$ \\
\hline Carbofuran $10 \mathrm{~F}^{\mathrm{a}}$ & 0.5 & $4.0 \mathrm{~b}$ & 15.la & $1.01 \mathrm{a}$ & $23.00 \mathrm{~b}$ & $17.2 \mathrm{c}$ & $2.46 a$ & $3.56 \mathrm{~b}$ \\
\hline Control & 0.0 & $7.8 \mathrm{a}$ & $9.7 \mathrm{c}$ & $0.62 \mathrm{ab}$ & $65.82 \mathrm{a}$ & $18.4 \mathrm{bc}$ & $3.77 \mathrm{a}$ & $2.21 \mathrm{c}$ \\
\hline
\end{tabular}

Means within a column, followed by a common letter, are not significantly different at the $5 \%$ level, by Duncan's multiple range test.

a. Formulations were injected into the root zone area with the aid of a row marker injector, 1 day before transplanting.

b. Strip formulation mounted on cardboard and inserted manually close to the plant base and to a depth of $5 \mathrm{~cm}$. 
At the lower application rate of $0.5 \mathrm{~kg}$ of carbofuran per ha, the CLF 45 microgranule gave consistently higher control levels than the flowable formulations, although not at a statistically significant difference. This can be interpreted as increased persistence at any chosen level of insect control.

Additional benefits of the controlled-release forms of carbofuran are evident from the observations presented in Table 3 . At $0.5 \mathrm{~kg}$ (AI)/ha, the percentage of deadhearts was reduced compared with the flowable formulation when root zone injected, although not significantly different from the control. However, the most striking effect was the percentage of hills infected with tungro virus estimated at 91 DT. CLF 45 microgranule at $0.5 \mathrm{~kg}$ (AI)/ha provided as much protection against transmission of tungro virus as the conventional formulations at $1.5 \mathrm{~kg}$ (AI)/ha. The CLFG 15 formulations gave complete control of the virus disease throughout the period of crop growth. This effect may be related to the high crop yields obtained with this formulation through an improved antifeedant response to the insecticide (Heinrichs et al. 1981). This formulation also resulted in a statistically significant increase in the productive tillers per hill, possibly due to the stimulation of plant growth by carbofuran (Venugopal and Litsinger 1979) ${ }^{2}$ enhanced by greater efficiency in delivery to the roots. The percentage of whiteheads due to late stem borer attack was also reduced by this formulation when compared with the others.

These beneficial trends were reflected in the grain yields obtained, with CLFG 15 at 1.5 $\mathrm{kg}(\mathrm{AI}) /$ ha giving the highest yield $-8 \%$ over the best conventional flowable formulation. However, the higher efficiency of the controlled release formulations is best demonstrated at low application rates, where losses in the soil become more critical. Thus, CLF $45 \mathrm{mi}-$ crogranules at $0.5 \mathrm{~kg}(\mathrm{AI}) / \mathrm{ha}$ gave a grain yield not significantly different from that provided by $1.5 \mathrm{~kg}(\mathrm{AI}) / \mathrm{ha}$ of the conventional flowable formulation, even though it was injected into the root zone. The evidence provided by these field trials gives some support to the concept that greater efficiency, leading to reduced application rates or longer effective periods, can be achieved through controlled release (Allan et al. 1973). Under the conditions of flooded rice it appeared that, although the period of useful insect control as determined using the cage plant technique was increased compared with conventional treatments, substantial extensions were not obtained with the lignin formulations. This was in accord with the release rate properties determined under laboratory conditions (Wilkins 1983). The experimental formulations were based on a biodegradable matrix designed to give complete release and to avoid undue residues in the crop or soil. Although additional work is needed to establish the soil insecticide concentrations with these formulations, our results suggest that the controlled-release approach can be effective in improving insecticide efficiency in flooded rice.

Acknowledgment - We acknowledge the support of the Leverhulme Trust during the development of the controlled-release formulations and to the Centre for Overseas Pest Research London (now part of the Tropical Development and Research Institute) for support during the field trials. 


\section{Notes}

1. P. van Halteren and S. Sama. 1976. The place of root zone application method in an integrated insect control program for rice in South Sulawesi, Indonesia. International Rice Research Conference, Manila, Philippines, 12-15 April 1976.

2. M. S. Venugopal and J. A. Litsinger. 1980. Carbofuran-a direct growth stimulant of rice. Saturday Seminar, 24 May 1980. International Rice Research Institute, Los Banos, Laguna, Philippines.

\section{References Cited}

Abbott, W. S. 1925. Method of computing the effectiveness of an insecticide. J. Econ. Entomol. 18: 265-267.

Allan, G. G., C. S. Chopra, J. F. Friedhof, R. I. Gara, M. W. Maggi, A. N. Neogi, S. C. Roberts, and R. M. Wilkins. 1973. Pesticides, pollution and polymers. Chem. Technol. 4: 171-178.

Allan, G. G., and A. N. Neogi. 1978. U.K. Patent 1502441 (1 March 1978).

Anonymous. 1980. Standard Evaluation System for Rice. International Rice Research Institute, Manila, Philippines, 2nd ed.

Aquino, G. B., and M. D. Pathak. 1976. Enhanced absorption and persistence of carbofuran and chlordimeform in rice plants on root zone applications under flooded conditions. J. Econ. Entomol. 69: 686-690.

Bowling, C. C. 1970. Lateral movement, uptake, and retention of carbofuran applied to flooded rice plants. Ibid. 63: 239-242.

Collins, H. L., N. Foster, S. Cade, N. Gauthier, and A. F. Kydonieus. 1981. Conventional agrichemical controlled release formulations for agriculture, forestry, and food protection, pp. 66-67. In Proc. 8th Int. Symp. Controlled Release of Bioactive Materials, Ft Lauderdale, Fla.

Dellicolli, H. T. 1977. Controlled release of pesticides from kraft lignin carriers, pp. 84-93. In H. B. Scher [ed.], Controlled release pesticides. Am. Chem. Soc., Washington, D.C.

Dellicolli, H. T. 1980. Pine kraft lignin as a pesticide delivery system, pp. 225-234. In A. F. Kydonieus [ed.], Controlled release technologies: methods, theory, and applications. Vol. 1. CRC Press, Boca Raton, Fla.

Gauthier, N. L. 1981. Controlled release formulations and their use in insect crop protection, pp. 259274. In D. H. Lewis [ed.], Controlled release of pesticides and pharmaceuticals. Plenum Press, New York.

Gomez, K. A., and A. A. Gomez. 1976. Statistical procedures for agricultural research with emphasis on rice. International Rice Research Institute, Los Baños, Philippines.

Heinrichs, E. A. 1979. Control of leafhopper and planthopper vectors of rice viruses, pp. 529-560. In K. Maramorosch and K. F. Harris [eds.], Leafhopper vectors and plant disease agents. Academic Press, Inc., New York.

Heinrichs, E. A., S. Chelliah, S. L. Valencia, M. B. Arceo, L. T. Fabellar, G. B. Aquino, and S. Pickin. 1981. Manual for testing insecticides on rice. International Rice Research Institute, Los Baños, Philippines.

Pathak, M. D., D. Encarnacion, and H. Dupo. 1974. Application of insecticides in the root zone of rice plants. Ind. J. Plant Prot. 1: 1-16.

Seiber, J. N., E. A. Heinrichs, G. B. Aquino, S. L. Valencia, P. Andrade, and A. M. Argente. 1978. Residues of carbofuran applied as a systemic insecticide in irrigated wetland rice: implications 
for insect control. IRRI Research Paper Series No. 17. International Rice Research Institute, Manila, Philippines.

Stokes, R. A., R. Coppedge, D. L. Bull, and R. L. Ridway. 1973. Use of selected plastics in controlled release granular formulations of aldicarb and dimethoate. J. Agric. Food Chem. 21: 103-109.

Thompson, H. E., G. G. Allan, and A. N. Neogi. 1981. The control of pine tip moths by using sustained release systemic insecticides. Int. Pest Control 23: 10-11.

Wilkins, R. M. 1981a. The use of controlled release herbicides in the establishment of conifer plantations, pp. 261-268. In G. H. Williams [ed.], Proc. Crop Protection in Northern Britain. British Crop Protection Council, Croydon.

Wilkins, R. M. 1981b. The design and use of lignin-based controlled release formulations for pest control in tropical rice, pp. 72-73. In Proc. 8th Int. Symp. Controlled Release of Bioactive Materials, Ft. Lauderdale, Fla.

Wilkins, R. M. 1983. Lignins as formulating agents for controlled release in agriculture. Br. Polymer J. 15: 177-178. 